\title{
Pasture and tussock responses to a single application of nitrogen or a full development process for drier hill country over two years
}

\author{
B.R. THOMPSON and D.R. STEVENS \\ AgResearch Ltd., Invermay Research Centre, Private Bag 50034, Mosgiel \\ bryan.thompson@agresearch.co.nz
}

\begin{abstract}
Increasing production from drier hill country to maintain economic viability must be balanced with environmental impacts and the preservation of the tussock landscape. This trial investigated the use of a one-off autumn application of nitrogen $(100 \mathrm{~kg} \mathrm{~N} / \mathrm{ha})$ to increase pasture production from drier hill country over subsequent seasons while maintaining the tussock biota. Comparative controls and previously oversown blocks were included. The response to nitrogen in the first winter-spring period was approximately $13 \mathrm{~kg} \mathrm{DM} /$ $\mathrm{kg} \mathrm{N}$ applied with no measurable response occurring thereafter. The oversown block produced around 3200 $\mathrm{kg} / \mathrm{DM} / \mathrm{annum}$ more than the other blocks, as expected in the first two years. The botanical analysis showed that browntop reinvasion of recently oversown pasture was rapid, increasing to a presence of over $50 \%$ in three years. Tussocks decreased in size in the nitrogen treated block, but this was possibly due to management practices rather than a response to fertiliser nitrogen. This trial highlights some of the issues that surround the optimal use of nitrogen fertiliser in drier hill country and also documents the invasion of less desirable grasses into the preferred developed pastures.
\end{abstract}

Keywords: Nitrogen, tussocks, oversowing

\section{Introduction}

Pasture production from hill country can be increased through a multitude of practices which have been demonstrated on farms since European settlers arrived in this country. In considering a development strategy, farmers have to balance the societal and regulatory responsibility of limiting their environmental footprint and maintaining the aesthetic value of the landscape while ensuring they operate a profitable business.

Oversowing with preferred grass and legume seed has long been used to increase pasture production from hill country. Herbicides have been used in recent times to eliminate competition from naturally occurring grass and scrub species to improve the chance of seed survival and establishment. This method also eliminates the endemic tussock and scrub species which can be beneficial for stock as shelter, particularly during the lambing and calving seasons (Pollard 2006).

Another approach that farmers can use to increase pasture production while maintaining the tussock and scrub cover is the tactical use of nitrogen. When applied during the autumn to early spring period it has been demonstrated to provide a range of increases in pasture productivity in hill country (Gillingham et al. 2007; Lambert \& Clark 1986; Lambert et al. 2003; Ledgard et al. 1983). The effect on pasture growth depends on the timing of application in regards to initial and residual responses, but generally the response occurs over the first two to three months (Ledgard et al. 1983; Luscombe 1980; O'Connor \& Gregg 1972; Sherlock \& O'Connor 1974; Smith et al. 2000). Recent research undertaken as part of the Wise Use of Nitrogen research program indicated that increases in pasture productivity from nitrogen application could be detected up to 18 months after application.

This demonstration was set up in conjunction with the South Canterbury/North Otago Deer Farmers Association Deer Focus Farm to investigate the effects on pasture and tussocks of a single application of nitrogen over a two-year period. A double sprayed oversown block was also monitored as a comparison between development methods.

\section{Materials and Methods \\ Sites}

This demonstration was conducted across two sites, Whiterock Station $\left(43^{\circ} 44^{\prime} \mathrm{S}, 171^{\circ} 10^{\prime} \mathrm{E}\right)$ and Waikari Hills Station $\left(43^{\circ} 47^{\prime} \mathrm{S}, 171^{\circ} 12^{\prime} \mathrm{E}\right)$, both in the Rangitata Gorge, South Canterbury. At Whiterock Station, two blocks, one control and one nitrogen block (nitrogen 2008) (100 kg N/ha) were set up on 27 March 2008 to compare and monitor pasture growth, quality and composition on base pastures consisting of historical oversown grass and legume species interspersed with silver (Poa cita) and snow (Chionocholoa rigida) tussocks and matagouri (Discaria toumatu) scrub. The blocks were south-westerly facing and at an altitude between 600-700 m.a.s.l. with an average annual rainfall of approximately $700 \mathrm{~mm}$. The blocks had received applications of sulphur superphosphate and lime previously and in 2004 received $0.5 \mathrm{~T} / \mathrm{ha}$ of lime and $40 \mathrm{~kg} / \mathrm{ha}$ of Maxi Sulphur superphosphate (5.1, 47.0 , and $11.0 \mathrm{~kg} / 100 \mathrm{~kg}$ of $\mathrm{P}, \mathrm{S}$, and Ca respectively) to maintain soil fertility and $\mathrm{pH}$. The nitrogen treatment was applied aerially using a helicopter during the 
Table 1. Pasture accumulation in $\mathrm{kg} \mathrm{DM} / \mathrm{ha}$ per season for the five blocks compared.

\begin{tabular}{lccccccccc}
\hline & 2008 & 2008 & $2008-09$ & 2009 & 2009 & 2009 & $2009-10$ & 2010 & 2010 \\
& Winter & Spring & Summer & Autumn & Winter & Spring & Summer & Autumn & Winter \\
\hline Waikari Hills Oversown & 253 & 2854 & 3155 & 488 & 232 & 3160 & 4998 & 1290 & 1020 \\
Waikari Hills Control & 49 & 1200 & 2276 & 223 & 127 & 2143 & 3723 & 1039 & 927 \\
Whiterock Control & 16 & 726 & 1834 & 309 & 200 & 2565 & 2744 & 691 & 1053 \\
Whiterock Nitrogen 08 & 159 & 1898 & 1800 & 319 & 221 & 2776 & 3007 & 489 & 776 \\
\hline
\end{tabular}

autumn of 2008 when weather conditions were deemed to be suitable. At Waikari Hills, two blocks were set up on 27 May 2008 and consisted of an unimproved tussock control block and a fully developed oversown block adjacent to the control block. Blocks were northwesterly facing and ranged between 750-850 m.a.s.1. with an average annual rainfall of around $1000 \mathrm{~mm}$. The oversown block was sprayed with two applications of glyphosate (4 L/ha, glyphosate $510 \mathrm{~g}$ a.i./L) in December and January 2006, oversown with rape and Italian ryegrass for winter and spring grazing and then sprayed twice more in late spring 2007 prior to sowing with a permanent pasture species mix of perennial ryegrass, cocksfoot and white clover. It was fertilised (250 kg/ha sulphur superphosphate) and limed (2 t/ha) to optimise pasture production.

\section{Measurements}

Pasture species composition was monitored over a two-year period using three $30 \mathrm{~m}$ transect lines in each block. Transect lines on Whiterock Station were located adjacent to one another $30 \mathrm{~m}$ apart and ran upslope covering a range of vegetative cover to ensure a representative sample was monitored. The transect lines on Waikari Hills Station were selected to cover the dry ridge, mid slope and basin features of the respective blocks. The four most prominent pasture species present were recorded in order of dominance ( 1 being the most dominant to 4 being the least dominant) within a $5 \mathrm{~cm}$ radius at 1 meter intervals along the transect lines. This data allowed a frequency of occurrence to be calculated for statistical analysis. The base circumferences of tussocks were measured in centimetres when encountered. The species present were assessed at trial setup, spring 2009, and 2010 when the trial finished.

Pasture growth was monitored 6-weekly during spring, summer and autumn and once during midwinter, using pasture cages excluding stock grazing, with one cage per transect line. Pasture was trimmed to approximately $800-1000 \mathrm{~kg} \mathrm{DM} /$ ha with clippings being removed. Growth rates were calculated using data obtained from a F400 electronic rising plate meter (Farmworks Ltd, Palmerston North, New Zealand).

Pasture quality samples were collected during growth measurements and were analysed by FeedTECH Ltd, Palmerston North, New Zealand using the standard
NIR feed test.

Soil samples were collect three times during the trial coinciding with the transect line species recording. Soil cores were collected along the transect lines down to $7.5 \mathrm{~cm}$ and sent to NZ Labs for analysis for a standard elemental test.

\section{Statistical analysis}

As the site was primarily for demonstration, the transect lines and cages provided pseudo-replication within each block. The data was analysed using a random estimate of maximum likelihood (REML) analysis (Genstat 2011) with site being treated as a fixed effect and transect as the random effect. The change in pasture composition over time used a repeated measures in time analysis.

\section{Results}

The nitrogen treated block on Whiterock Station produced $1300 \mathrm{~kg} \mathrm{DM} /$ ha more pasture than the control block during the first winter-spring period (late Maylate October) (Table 1) resulting in an response rate of $13 \mathrm{~kg} \mathrm{DM} / \mathrm{kg} \mathrm{N}$ applied. Similar pasture accumulation occurred for the following year for these two blocks. The Waikari Hills oversown block produced approximately $3200 \mathrm{~kg} \mathrm{DM} / \mathrm{ha} /$ year more than the other blocks in the trial, with the comparative unimproved (control) block producing around the same quantity of pasture annually as the Whiterock blocks. Average pasture production was different between the three slopes for spring $(\mathrm{P}=0.038)$, summer $(\mathrm{P}=0.018)$ and winter $(\mathrm{P}=0.024)$ on the Waikari Hills blocks.

The Waikari Hills oversown block had less browntop (Agrostis capillaris) $(\mathrm{P}<0.05)$ and more ryegrass $(\mathrm{P}<0.001)$ than the other blocks. There was a trend to an increasing amount of browntop in the Waikari Hills oversown block, this grass occurring at $24 \%$ of the transect points initially and increasing to over $50 \%$ of the points at the last measure. There was also a trend to a decreasing amount of ryegrass $(81 \%$ decreasing to $72 \%$ ) over time. On Whiterock Station there was an increase $(\mathrm{P}<0.05)$ in the occurrence of ryegrass in the nitrogen treated block ( $18 \%$ increasing to over $58 \%$ ), with the comparative control block increasing slightly but not significantly (44 to 69\%). There was also a trend for white clover content to decrease during the trial for 
both the nitrogen treated block and the comparative control block, reducing from 48 to $31 \%$ and 67 to $61 \%$ respectively. Cocksfoot increased but not significantly in the Waikari Hills oversown block from 8 to $23 \%$ but did not differ in the other trial blocks.

Tussock total counts varied between blocks $(\mathrm{P}<0.05)$ ranging from 2.33 and 6.00 tussocks per transect line for the Whiterock nitrogen treated block and Waikari Hills control blocks respectively, but there were no interactions with time. Silver tussock accounted for the majority of tussocks recorded, accounting for between $81-92 \%$ of total tussocks encountered over the three recording periods. There was a decreasing linear relationship ( $\mathrm{P}=0.029)$ over time for individual average tussock circumference $(\mathrm{cm})$ in the Whiterock nitrogen treated block, reducing from 162 to $7 \mathrm{~cm}$. There was no change in size of snow tussocks during the same period, demonstrating that all of the change occurred in the silver tussocks.

Pasture metabolisable energy contents (ME) were higher for the Waikari Hills oversown block (11.18 and $10.98 \mathrm{MJ} / \mathrm{kg} \mathrm{DM}$ for year 1 and 2 respectively) than the control block $(9.98$ and $10.11 \mathrm{MJ} / \mathrm{kg}$ DM for year 1 and 2 respectively) in both years $(\mathrm{P}<0.001)$. There were no differences in pasture ME between the Whiterock blocks in year 1 (10.53 and $10.34 \mathrm{MJ} / \mathrm{kg} \mathrm{DM})$ or year $2(11.09$ and $11.21 \mathrm{MJ} / \mathrm{kg} \mathrm{DM})$. Pasture ME differed between seasons in year $1(\mathrm{P}=0.004)$ and year $2(\mathrm{P}<0.001)$, with the highest values recorded during spring (10.96 and $11.14 \mathrm{MJ} / \mathrm{kg} \mathrm{DM}$ for years 1 and 2 respectively) and declining over summer and autumn and reaching their lowest values in winter $(9.79 \mathrm{MJ} / \mathrm{kg}$ DM in year 1, no data for year 2). Pasture crude protein (CP) differed between the two Waikari Hills blocks in year 1 (20.67 and $24.15 \mathrm{~g} / 100 \mathrm{~g}$ DM for the control and oversown blocks respectively) $(\mathrm{P}<0.05)$ but not in year 2 (22.12 and $23.61 \mathrm{~g} / 100 \mathrm{~g} \mathrm{DM})$. Crude protein values did not differ between the Whiterock blocks within each year with values of 22.03 and $22.06 \mathrm{~g} / 100 \mathrm{~g}$ DM in year 1 and 24.43 and $24.79 \mathrm{~g} / 100 \mathrm{~g} \mathrm{DM}$ for the control and nitrogen treated block respectively. There were no differences in CP values between seasons.

Soil tests indicated that the soil fertility was adequate and that a good response to nitrogen could be expected.

\section{Discussion}

The response to the first application of nitrogen is within the range described by Gillingham et al. (2007) and Smith et al. (2004) for similar environments. There were, however, no pasture production effects detected in the following autumn or in year 2 such as those demonstrated by previous work in the Wise Use of Nitrogen Western Southland trial. In the Western Southland demonstration the key responses were recorded during the spring periods when ewes and lambs were set stocked for lambing. In the first spring following the autumn application of $100 \mathrm{~kg} \mathrm{~N} / \mathrm{ha}$, the stocking rate increased by $64 \%$, while in the second spring the stocking rate was still $37 \%$ higher, some 18 months after application. The winter management of intensive mob grazing by sheep may have provided a recycling of the fertiliser nitrogen at the Western Southland site, while the low impact set stocking at Whiterock did not.

The large increase in pasture production achieved in the Waikari Hills oversown block was as anticipated. The majority of extra growth occurred in spring and summer as would be expected due to the growth pattern of ryegrass.

The trend to an increasing occurrence of ryegrass and a decrease in legume in the sward of the nitrogen treated block is similar to other research findings (Gillingham et al. 2008; Ledgard et al. 1983; Smith et al. 2004). In general, the change in occurrence of the legume in the sward is a direct result of the increasing amount of grass growth in response to nitrogen application. This increased grass growth competes with and shades the legume plant. The smaller response of the grass to nitrogen application in this trial could also explain the smaller reduction in clover content, as the same degree of competition and shading would not have resulted. This also highlights the importance of grazing management of the increased growth as an important factor in helping minimising the negative effect on clover content.

The trend to a decreasing occurrence of ryegrass in the sward on Waikari Hills oversown block indicates that the use and benefits from ryegrass in this hill country may be short lived, which was also demonstrated by Chapman \& Campbell (1986) in moist North Island hill country. To confirm this, further research lasting over an extended period of time would be required. The increase in the occurrence of cocksfoot in the sward from 8 to $23 \%$ demonstrates the relatively slow establishment of this grass species as described by Scott et al. (1995), but also indicates that cocksfoot may persist for a longer period in this environment when compared to ryegrass. To maintain persistence of cocksfoot it is important that grazing is rotational and at a low to moderate density (Scott et al. 1995).

Tussock numbers along the transect lines did not change significantly during the trial period but it must be noted that numbers were low, particularly for snow tussock, with a large variability between transect lines within any given block. It is not known at this stage whether the decrease in total size and individual size of tussocks in the Whiterock nitrogen treated block was due to management strategies at the site of the 
transects, or whether the nitrogen made the tussocks more palatable for the grazing animals. It was noted that the area had been used occasionally as a feed out area during the winter, but this may or may not have impacted on the tussocks. Further research is needed to determine this. Tussocks were not present on the Waikari Hills oversown block as a result of the application of herbicide during the development process, and as a consequence were excluded from the analysis.

There were no recorded effects on ME and crude protein content of pasture that had received nitrogen application over that of the control block. The pastures on Whiterock were generally of very high quality due to the grazing management utilised on these blocks, so a change would not be expected. The increase in pasture quality in the first year for the Waikari Hills oversown block may be a result of an increasing amount of ryegrass and white clover in the sward. The drop in quality in the second year is potentially a result of other grasses increasing in the sward.

In conclusion, farmers who choose to keep tussocks can use nitrogen to increase pasture production in the short term with the direct effects to the tussocks inconclusive at this stage. The oversowing program used in this trial does eliminate tussock but also increases pasture production significantly. There is an indication that this extra pasture production will diminish with time as the amount of ryegrass in the sward decreases due to the reinvasion of undesired grasses.

\section{ACKNOWLEDGEMENTS}

The authors would like to thank the Sustainable Farming Fund and DeeResearch Ltd for financial support, Ross and Sally Stevens and John Acland for the use of their farms, and Agresearch Invermay staff for technical assistance.

\section{REFERENCES}

Chapman, D.F.; Campbell, B.D. 1986. Establishment of ryegrass, cocksfoot, and white clover by oversowing in hill country. 2. Sown species and total herbage accumulation. New Zealand Journal of Agricultural Research 29: 33-37.

Genstat 2011. Genstat for Windows, VSN International Ltd, Oxford.

Gillingham, A.G.; Morton, J.D.; Gray, M.H. 2007. Pasture responses to phosphorus and nitrogen fertilisers on East Coast hill country: total production from easy slopes. New Zealand Journal of Agricultural Research 50: 307-320.

Gillingham, A.G.; Morton, J.D.; Gray, M.H. 2008.
Pasture responses to phosphorus and nitrogen fertilisers on east coast hill country: 2. Clover and grass production from easy slopes. New Zealand Journal of Agricultural Research 51: 85-97.

Lambert, M.G.; Clark, D.A. 1986. Effects of lateautumn nitrogen application on hill country pastures and sheep production. Proceedings of the New Zealand Grassland Association 47: 211-215.

Lambert, M.G.; Mackay, A.D.; Devantier, B.P.; McDougal, D.B.; Barker, D.J.; Park-ng, Z.A. 2003. Redefining the production potential of hill pastures using fertiliser nitrogen. Proceedings of the New Zealand Grassland Association 65: 35-40.

Ledgard, S.F.; Brier, G.J.; Gillingham, A.G.; Sheath, G.W. 1983. Influence of some soil and pasture components on the growth of hill country pastures. II. Response to nitrogen fertiliser. New Zealand Journal of Experimental Agriculture 11: 251-256.

Luscombe, P.C. 1980. Nitrogen fertilizer responses on hill country pastures. Proceedings of the New Zealand Grassland Association 41: 155-162.

O'Connor, M.B.; Gregg, P.E.H. 1972. Nitrogen fertilizer trials on pastures. Proceedings of the New Zealand Grassland Association 33: 26-34.

Pollard, J.C. 2006. Shelter for lambing sheep in New Zealand: a review. New Zealand Journal of Agricultural Research 49: 395-404.

Scott, D.; Maunsell, L.A.; Keoghan, J.M.; Allan, B.E.; Lowther, W.L.; Cossens, G.G. 1995. Description of species $A$ guide to pastures and pasture species for the New Zealand high country. Grassland Research \& Practice Series 4: 34.

Sherlock, R.R.; O'Connor, M.B. 1974. The use of nitrogen on hill country. Proceedings of the New Zealand Grassland Association 35: 52-62.

Smith, L.C.; Morton, J.D.; Catto, W.D.; Trainor, K.D. 2000. Nitrogen responses on pastures in the southern South Island of New Zealand. Proceedings of the New Zealand Grassland Association 62: 19-23.

Smith, L.C.; Morton, J.D.; Trainor, K.D.; Catto, W.D. 2004. Application of nitrogen and sulphur to sunny and shady aspects on South Island dry hill country. Proceedings of the New Zealand Grassland Association 66: 41-47. 